\title{
The Effect of Dropwise Addition of Medium on the Yield of Carbon-limited Cultures of Arthrobacter globiformis
}

\author{
By B. M. LUSCOMBE \\ Department of Biochemistry and Microbiology, Cook College, \\ Rutgers Universit!, New Brunswick, New Jersey, U.S.A. \\ (Received 29 January 1974; revised 25 March 1974)
}

INTRODUCTION

It is a common feature of carbon-limited chemostat cultures that the yield becomes lowered at low dilution rates (e.g. Herbert, 1959, 1961). This has usually been attributed to a maintenance energy requirement, but Brooks \& Meers (1973) suggested another possible cause. In studying the effect of discontinuous addition of methanol to 'continuous' cultures of Pseudomonas, they found a decrease in yield as the time between additions was extended from 20 to $100 \mathrm{~s}$. They suggested that either methanol was 'wasted' during periods of excess which followed methanol addition, or, in growing intermittently, organisms were using energy in continually adjusting their physiology and consequently less substrate was available for incorporation into cell material. It seems the decrease in yield usually obtained with carbon-limited cultures could be caused by intermittent growth produced by the discontinuous or dropwise addition of substrate, the effect becoming more pronounced as the dilution rate decreases and greater time elapses between additions.

Obviously, with dropwise addition of substrate there is an increase in substrate concentration in the culture at the instant of addition, so the effect of this increase should be considered. Glucose-limited cultures of Arthrobacter globiformis show a lowered yield at dilution rates below $0 \cdot 1$ h ${ }^{1}$ (Luscombe \& Gray, 1974). The following experiment was designed to determine whether this decrease could be due to the dropwise addition of medium.

\section{METHOD}

Arthrobacter globiformis (NCIBI 0683) was grown under air in a chemostat with a working volume of $260 \mathrm{ml}$, stirred with a four-bladed paddle at $500 \mathrm{rev} . / \mathrm{min}$. The medium used was the defined salts ' $E$ ' of Owens \& Keddie (1969); salt concentrations were doubled except $\left(\mathrm{NH}_{4}\right)_{2} \mathrm{SO}_{4}$ which was tripled, with biotin $(2 \mu \mathrm{g} / \mathrm{l})$ and glucose $(\mathrm{I} \cdot 8 \mathrm{~g} / \mathrm{l})$ as the limiting carbon sources. Dilution rates of $0.0 \mathrm{I}, 0.05$ and $0.1 \mathrm{~h}{ }^{1}$ were employed at $25^{\circ} \mathrm{C}$.

The medium was added dropwise to the culture. The medium supply-line was divided so that the flow could be directed through either of two droppers. One dropper consisted of a 22 gauge hypodermic needle, the other an $8 \mathrm{~mm}$ diam glass tube which released drops approximately eight times larger than those produced by the needle. At each dilution rate, medium was introduced through one of the droppers, and when a steady state had been established the yield was determined. Medium flow was then switched to the other dropper and the yield was again determined at the 'new' steady state. The yield was also determined at a dilution rate of $0.2 \mathrm{~h}^{1}$ using the smaller drops.

Yield was measured by filtering a known volume of culture through a preweighed membrane filter, washing with deionized water, drying at $105{ }^{\circ} \mathrm{C}$, and weighing. 


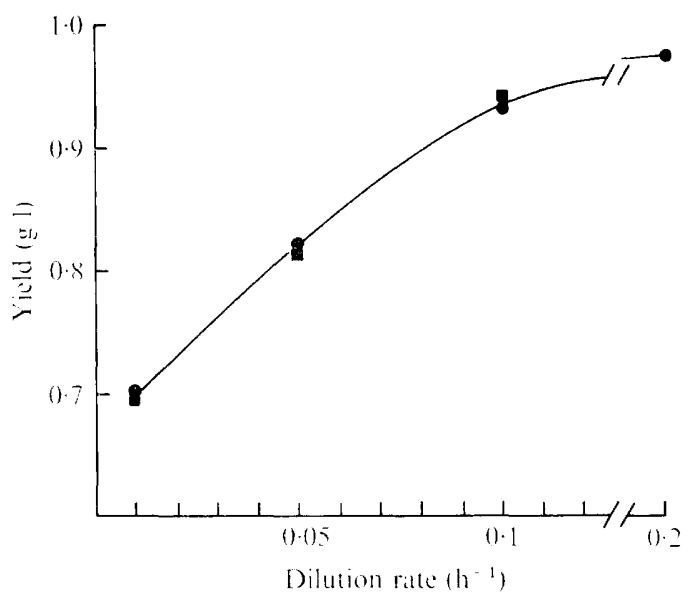

Fig. I. The effect of dropwise addition of substrate and dilution rate on the yield of Arthrobacter globiformis in a carbon-limited chemostat;, $0.0 \mathrm{I} \mathrm{ml}$ drops;, $0.08 \mathrm{ml}$ drops.

\section{RESULTS AND DISCUSSION}

The hypodermic needle gave drops of about $0.01 \mathrm{ml}$, the glass tube about $0.08 \mathrm{ml}$. These drop sizes gave time lapses of $\mathrm{I} 5$ and $\mathrm{I} 20 \mathrm{~s}$ at a dilution rate of $0.0 \mathrm{I} \mathrm{h} \mathrm{h}^{-1}, 3$ and $24 \mathrm{~s}$ at $0.05 \mathrm{~h}^{-1}$, and $\mathrm{I} \cdot 5$ and $\mathrm{I} 2 \mathrm{~S}$ at $\mathrm{O} \cdot \mathrm{I} \mathrm{h}^{-1}$. At none of the dilution rates used was there any difference between yields obtained with either drop size (Fig. 1). Lowered yields of Arthrobacter globiformis at dilution rates below $0 . \mathrm{I} \mathrm{h}^{-1}$ under carbon limitation thus cannot be attributed to the mode of substrate addition; the suggestion that the effect is caused by a maintenance energy requirement remains more plausible.

Brooks \& Meers (I973) have shown that growth can be affected by the discontinuous addition of substrate, so it would be wise to remember this in designing a continuous culture system, though their results do not have such wide-reaching implications as was initially thought.

This is a paper of the Journal Series, New Jersey Agricultural Experiment Station, Cook College, Rutgers University, New Brunswick, New Jersey, U.S.A. The author was supported by a fellowship from Rutgers University.

\section{REFERENCES}

Brooks, J. D. \& MeERs, J. L. (1973). The effect of discontinuous methanol addition on the growth of a carbon-limited culture of Pseudomonas. Journal of General Microbiology 77, 513-519.

Herbert, D. (1959). Some principles of continuous culture. In Recent Progress in Microbiology, vol. 7, pp. 381-396. Edited by G. Tunevall. Oxford: Blackwell's Scientific Publications.

HERBERT, D. (1961). The chemical composition of microorganisms as a function of their environment. In Microbial Reaction to Environment. Symposia of the Society for General Microbiology Ir, 391-416.

Luscombe, B. M. \& Gray, T. R. G. (I974). Characteristics of Arthrobacter grown in continuous culture. Journal of General Microbiology 82, 213-222.

OWENS, J. D. \& KedDIE, R. M. (1969). The nitrogen nutrition of soil and herbage coryneform bacteria. Journal of Applied Bacteriology 32, 338-347. 